\title{
Sustainability of a Moodle-Based Learning Management System (LMS) Based on Post-graduate Students' Perspectives
}

\author{
Hablil Warid ${ }^{1}$, Lailatul Musyarofah ${ }^{2}$, Kani Sulam Taufik ${ }^{3}$ \\ ${ }^{1,2,3}$ STKIP PGRI Sidoarjo \\ hablil.saja@gmail.com,Ibulaila7810@gmail.com,sullamtaufik@gmail.com
}

\begin{abstract}
Moodle is an open-source Learning Management System (LMS) that is gaining popularity in STKIP PGRI Sidoarjo's educational institution. While the education department has accepted Moodle, successfully implementing it for post-graduate students at STKIP PGRI Sidoarjo would then require student acceptance. However, the LMS is the ideal approach for increasing students' commitment to educational content such as sustainability. The findings indicated that students' desire to use LMS SIDALACE, Sidoarjo Learning Space, had a beneficial effect on learning as sustainability engagement during the COVID-19 pandemic. Additionally, students perceived closeness, peer references, and subjective well-being are positively associated with perceived ease of use and perceived usefulness, which influences students' intentions to use, which in turn influences LMS usage for student engagement during Covid-19.
\end{abstract}

\section{Keywords}

Sustainability; LMS; perspective; post-graduate

\section{Introduction}

The outbreak of this virus has an impact of a nation and Globally (Ningrum et al, 2020). The presence of Covid-19 as a pandemic certainly has an economic, social and psychological impact on society (Saleh and Mujahiddin, 2020). Covid 19 pandemic caused all efforts not to be as maximal as expected (Sihombing and Nasib, 2020).

After its initial appearance, the Covid-19 epidemic quickly spread to a truly global scale. While the virus's social spread raises concerns about the long-term viability of faceto-face education, a quick overview of the virus's growth provides context for how it has transformed teaching-learning and impacted student-teacher interactions (Alturki \& Aldraiweesh, 2021). As a result of the epidemic, universities were forced to conduct all student teaching and learning online. The necessity of using technology for educational purposes during the pandemic for the sake of education as a long-term solution is also unavoidable; some recent reports have brought this issue to light (Kerres, 2020). One of the technologies used during Covid-19 is the Learning Management System (LMS), which is a media integration for instructions that makes use of a single platform to coordinate communication processes during instructional events. Innovating technology networks like Edmodo, Google Classroom, Forum, EdX, MOOC and Coursera, as well as specialized education, use LMS as sustainability platforms. LMS can range from computer-managed learning to interactive LMS.

The implications of modern information technology are growing rapidly, and information and communication technologies (ICTs) are becoming increasingly common in universities, particularly in the educational process. The depths of new and innovative technologies continue to grow. The design of higher education course content, as well as online exposure to it, is a new trend. Technological advancements are increasing at an alarming rate from time to time and are being used in a wide range of activities through the 
use of the internet (Widodo \& Slamet, 2020). The use of ICT systems, such as Moodle, Google Classroom, Microsoft Teams, and Zoom Platforms Management Systems (LMS), asynchrony remote learning, online courses and tests, and a combination of traditional, face-to-face lectures, tutoring, and web-based teaching content have allowed academics and institutions of higher education to diversify their education over the past two decades (Alameri, Masadeh, Hamadallah, \& Bani, 2020).

In order to encourage more student participation and engagement, learning management systems (LMS) have been introduced as a technology. Virtual learning environments (VLEs), which have evolved from traditional learning methods, are now regarded as crucial learning analytics data sources for educational institutions (JO, Kim, \& Yoon, 2015). Furthermore, among the existing technology platforms available for delivering flipped classrooms, learning management systems (LMSs) stand out as the most commonly used due to their advantage in delivering course content and managing the enormous amount of information that online courses entail (Abdelraheem, 2012). The open-source Moodle (Modular Object-Oriented Dynamic Learning Environment) is the most widely used LMS (Machado \& Tao, 2007). It is possible to enforce online learning systems through the use of Moodle, which allows educators to share knowledge through a variety of activities that can be monitored, such as forums and chat sessions (Widodo \& Slamet, 2021). Consequently, it is possible to conclude that Moodle can improve learning outcomes and assist students in comprehending the lesson content.

Essentially, Moodle can be used to replace a traditional learning environment with a digital version. Discussion boards, course materials, and other resources are all available for educators to use. They can also hand out and grade assignments, as well as create quizzes with automatic grading. Students will always be able to see exactly what the assignment is, will be able to discuss the course with their peers, and will have all of the course's aspects in one convenient location with a straightforward layout (Adesope \& Ahiakwo, 2016). Moodle incorporates pedagogical features that are absent from many other learning management system tools, allowing instructors to create customizable online courses or a diverse range of course modules on a scalable and adaptable framework. Moodle can be installed on any computer and used to support a single instructor site or a large system with thousands of students, depending on the configuration. It is distributed under a general public license provided by the open-source initiative (Wheeler, 2010).

Moodle is an excellent tool for distance learning because of its ease of use, but it is really designed to work best with face-to-face classroom teaching rather than having the teaching and learning activities immediately shifted to a full E-learning environment. Although it certainly saves time and paperwork for teachers, the more important reason for educators to use it is that it allows students to learn more independently-that is, to have more control over their learning-as well as more cooperatively. E-learning is defined as learning that takes advantage of information and communication technologies (ICTs). Education has been transformed as a result of the incorporation of technological resources as well as innovative educational strategies into the curriculum. Previous studies have demonstrated that various e-learning and online learning tools are effective for teaching and learning in the fields of health professions, including dentistry (Moazami, Bahrampour, Azar, Jahedi, \& Moattari, 2014). Moodle-based e-learning has been shown to be equivalent to face-to-face methods in terms of knowledge gain and performance (Zogas, Kolokathi, Birbas, Chondrocoukis, \& Mantas, 2016).

More broadly, while the use of LMS such as Moodle-based systems undoubtedly provides new educational experiences for both teachers and students, how teachers and students perceive such reform efforts, their thoughts and experiences about the ICTs that 
are being used, their attitudes toward instructional applications, and their expectations, are important factors in the plan to increase the use of ICTs in educational settings (Lim \& Khine, 2006). To put it another way, the successful integration of computers into educational settings is highly dependent on the attitudes of teachers and students toward information and communication technologies (ICTs) and computers (Selwyn, 1999). It is also clear that investments in ICTs necessitate the integration of programs into classrooms and the orientation of students toward determining their knowledge of and attitudes toward these technologies.

During the Covid-19 pandemic, STKIP PGRI Sidoarjo as one of the private universities in Sidoarjo have implemented a learning management system (LMS) that utilized Moodle as a learning medium. With the transformation of face-to-face learning into e-learning, the existence of a learning management system (LMS) becomes a consideration in terms of its long-term viability. Known as SIDALCE (STKIP PGRI Sidoarjo Learning Space), the SIDALCE platform is used by the Master of English Education (MPBI) at STKIP PGRI Sidoarjo to manage learning materials and learning processes. Moreover, there have been some studies discuss a methodology that falls under the umbrella of e-learning as sustainability enabled the process of learning as sustainability to resume (Zwain, 2019). This technology is referred to as a Learning Management System (LMS), and its use in the process of learning as sustainability helps to promote e-learning as sustainability by providing instructional material that is not time or location-bound (Ain, Kaur, \& Waheed, 2016), enabling students and teachers to communicate via the internet, and facilitating the sharing of course-related information and resources (Lonn, Teasley, \& Krumm, 2011). In this research, the importance of post-graduate students' perceptions of the use of the LMS is the main topic of discussion in this research, and this is the case in this case.

The term "sustainability" can be interpreted in a variety of ways. The definition provided here establishes a common understanding of the research's objectives and outcomes, which serves as the foundation for the discussion that follows (Gunn, 2010). When all three of the following conditions are met, an e-learning initiative is considered to be sustainable: The development and implementation of a learning design that incorporates information and communications technology within a course or courses of study are described in detail below. It has gone through a proof-of-concept stage and has been determined to be beneficial to teaching and learning on the basis of the evidence that has been collected. (b) The e-learning concept, design, system, or resources have demonstrated the ability to be adopted, and possibly modified, for use in environments other than the one in which they were developed and (c) the maintenance, use, and further development of the e-learning concept, design, system, or resources are not dependent on one or a few individuals who created them to the extent that future prospects are not jeopardized if their involvement is discontinued.

Through seamless integration, a course-specific suite of e-learning activities integrates with and complements the enterprise LMS. When staff changes occur, the teamteaching approach ensures continuity. Additionally, it benefits from an internal community of professional practice, with academics of varying levels of experience cooperating on common goals. While no significant effort has been made to disseminate this high-profile e-learning design outside of the development context, it has won prominent teaching excellence awards and the model is freely available for adoption or adaptation by anyone. These types of initiatives could serve as models for institutional capacity development efforts of the type described by Salmon, Jones, and Armellini (2008). However, the majority of institutions do not analyze successful examples or use them to inform the 
implementation of their e-learning strategies. Referring to the importance of the sustainability of the LMS at STKIP PGRI Sidoarjo, the researchers focused on the discussion in this study through the perceptions of postgraduate students towards the use of LMS.

\section{Research Method}

This is a descriptive study designed to ascertain the sustainability of a Moodle-based learning management system, SIDALACE, by examining students' perceptions toward using Moodle for teaching. The participants comprised 20 post-graduate students at STKIP PGRI Sidoarjo during the third semester of the academic year 2021/2020. The samples were chosen because they were involved in the process of teaching through SIDALACE. The primary research instrument was a questionnaire, which was used to elicit quantitative data about students' perceptions of Moodle implementation. All research subjects were given the questionnaire, which was adapted from Adesope \& Ahiakwo (2016). To elicit valuable data on the aforementioned topics, a questionnaire was developed with the objective of eliciting information on three specific topics: the benefits of using Moodle for learning activities, the actual use of Moodle for learning activities, and students' attitudes toward Moodle for learning activities. The Likert scale identified four levels of agreement: Strongly Agree $(\mathrm{SA})=4$, Agree $(A)=3$, Disagree $(D)=2$, and Strongly Disagree $(\mathrm{SD})=$ 1.

The researchers analyzed the data after collecting it using a variety of techniques. The researchers began by analyzing the responses to the questionnaire. Second, the researchers calculated the mean of the acquired score by entering the frequencies into a table and converting them to percentages. The researchers classified the questionnaires based on the lecturers' perspectives scores after calculating the total percentage of questionnaires. The results of the questionnaire were classified into the following intervals:

Table 1. Interval the Frequency and Classification Level of Perspectives

\begin{tabular}{|l|c|}
\hline \multicolumn{1}{|c|}{ Interval the Frequency of Responds } & Classification Level \\
\hline $81 \%-100 \%$ & Very Good \\
\hline $61 \%-80 \%$ & Good \\
\hline $41 \%-60 \%$ & Average \\
\hline $21 \%-40 \%$ & Poor \\
\hline $0 \%-20 \%$ & Very Poor \\
\hline
\end{tabular}

Source: Sepyanda (2018)

\section{Result and Discussion}

The researchers summarized their findings in this section, which included administering a questionnaire to 20 postgraduate students at STKIP PGRI Sidoarjo and responding to various survey questions. The purpose of this study was to learn more about students' perceptions of Moodle implementation in relation to the LMS SIDALACE's sustainability. According to the results of the questionnaires examined using SPSS 26, the questionnaire's Cronbach alpha was 0.876. Cronbach's alpha coefficients for each field 
were greater than 0.8 , which was considered acceptable. Considering the students' perceptions of their prior experience with Moodle, it is possible to present the questionnaire results as follows:

Table 2. Results of Questionnaire

\begin{tabular}{|c|c|c|c|c|c|}
\hline No. & Statements & $\mathbf{S A}$ & $\mathbf{A}$ & $\mathbf{D}$ & SD \\
\hline \multicolumn{6}{|c|}{ Benefits of using Moodle for learning activities } \\
\hline 1 & $\begin{array}{l}\text { Moodle facilitates the generation of spaces } \\
\text { called Courses in which educational content } \\
\text { can be shared and students and lecturers can } \\
\text { interact. }\end{array}$ & $\begin{array}{l}90 \% \\
(18)\end{array}$ & $\begin{array}{c}10 \% \\
(2)\end{array}$ & $\begin{array}{l}0 \% \\
(0)\end{array}$ & $\begin{array}{l}0 \% \\
(0)\end{array}$ \\
\hline 2 & $\begin{array}{l}\text { Moodle gives students information about their } \\
\text { courses, as well as making it easy for students } \\
\text { to get to word documents, slides, and other } \\
\text { important resources. }\end{array}$ & $\begin{array}{l}70 \% \\
(14)\end{array}$ & $\begin{array}{c}30 \% \\
(6)\end{array}$ & $\begin{array}{l}0 \% \\
(0)\end{array}$ & $\begin{array}{l}0 \% \\
(0)\end{array}$ \\
\hline 3 & $\begin{array}{l}\text { With Moodle, lecturers can better work with } \\
\text { students as a team. }\end{array}$ & $\begin{array}{l}75 \% \\
(15)\end{array}$ & $\begin{array}{c}25 \% \\
(5)\end{array}$ & $\begin{array}{l}0 \% \\
(0)\end{array}$ & $\begin{array}{l}0 \% \\
\text { (0) }\end{array}$ \\
\hline 4 & $\begin{array}{l}\text { Students and lecturers get to know each other } \\
\text { right away. They also have the chance to keep } \\
\text { all the information about the course team and } \\
\text { students in one place. }\end{array}$ & $\begin{array}{l}75 \% \\
(15)\end{array}$ & $\begin{array}{c}25 \% \\
(5)\end{array}$ & $\begin{array}{l}0 \% \\
(0)\end{array}$ & $0 \%$ \\
\hline 5 & $\begin{array}{l}\text { Moodle gives lecturers the chance to make } \\
\text { recordings of lectures available as video } \\
\text { recordings of lectures or special events and } \\
\text { then make them available to students. }\end{array}$ & $\begin{array}{l}80 \% \\
(16)\end{array}$ & $\begin{array}{c}20 \% \\
\text { (4) }\end{array}$ & $\begin{array}{l}0 \% \\
(0)\end{array}$ & $(0)$ \\
\hline \multicolumn{6}{|c|}{ The usage of Moodle for learning activities } \\
\hline 6 & $\begin{array}{l}\text { Using Moodle to upload video, audio and/or } \\
\text { link to a lesson. }\end{array}$ & $\begin{array}{l}75 \% \\
(15)\end{array}$ & $\begin{array}{c}25 \% \\
(5)\end{array}$ & $\begin{array}{l}0 \% \\
(0)\end{array}$ & $\begin{array}{l}0 \% \\
\text { (0) }\end{array}$ \\
\hline 7 & Engage in a discussion forum. & $\begin{array}{l}70 \% \\
(14)\end{array}$ & $\begin{array}{c}30 \% \\
(6)\end{array}$ & $\begin{array}{l}0 \% \\
(0)\end{array}$ & $\begin{array}{l}0 \% \\
(0)\end{array}$ \\
\hline 8 & Guides a real-time discussion or chat. & $\begin{array}{l}70 \% \\
(14)\end{array}$ & $\begin{array}{c}30 \% \\
(6)\end{array}$ & $\begin{array}{l}0 \% \\
(0)\end{array}$ & $\begin{array}{l}0 \% \\
\text { (0) }\end{array}$ \\
\hline 9 & Create, conduct and guide quizzes & $\begin{array}{l}80 \% \\
(16)\end{array}$ & $\begin{array}{c}20 \% \\
(4)\end{array}$ & $\begin{array}{l}0 \% \\
(0)\end{array}$ & $\begin{array}{l}0 \% \\
(0)\end{array}$ \\
\hline 10 & $\begin{array}{l}\text { Assign, collect, review and upgrade } \\
\text { assignments. }\end{array}$ & $\begin{array}{l}75 \% \\
(15)\end{array}$ & $\begin{array}{l}25 \% \\
(5)\end{array}$ & $\begin{array}{l}0 \% \\
(0)\end{array}$ & $\begin{array}{l}0 \% \\
(0)\end{array}$ \\
\hline \multicolumn{6}{|c|}{ Attitude of Students' using Moodle for learning activities } \\
\hline 11 & $\begin{array}{l}\text { A new set of tools have been added into the } \\
\text { educational system so that it can be better at }\end{array}$ & $\begin{array}{l}70 \% \\
(14)\end{array}$ & $\begin{array}{l}30 \% \\
(3)\end{array}$ & $\begin{array}{l}10 \% \\
(3)\end{array}$ & $\begin{array}{l}0 \% \\
(0)\end{array}$ \\
\hline
\end{tabular}




\begin{tabular}{|c|l|c|c|c|c|}
\hline & teaching individuals. & & & & \\
\hline 12 & I can use Moodle for learning activities. & $50 \%$ & $30 \%$ & $20 \%$ & $0 \%$ \\
& & $(10)$ & $(6)$ & $(4)$ & $(0)$ \\
\hline 13 & Moodle is interesting. & $60 \%$ & $25 \%$ & $15 \%$ & $0 \%$ \\
& & $(12)$ & $(5)$ & $(3)$ & $(0)$ \\
\hline 14 & Computer skills is beneficial in using Moodle. & $85 \%$ & $15 \%$ & $0 \%$ & $0 \%$ \\
& $\begin{array}{l}\text { Using Moodle to design courses online inspires } \\
\text { me to become even more motivated. }\end{array}$ & $65 \%$ & $30 \%$ & $5 \%$ & $0 \%$ \\
\hline 16 & $\begin{array}{l}\text { Moodle makes it simple to communicate with } \\
\text { one another. }\end{array}$ & $65 \%$ & $35 \%$ & $0 \%$ & $0 \%$ \\
\hline 17 & $\begin{array}{l}\text { Using Moodle, both lecturers and students can } \\
\text { get a new way to learn. }\end{array}$ & $70 \%$ & $30 \%$ & $0 \%$ & $0 \%$ \\
& $\begin{array}{l}\text { It is necessary to receive instruction on how to } \\
\text { use Moodle in the classroom. }\end{array}$ & $60 \%$ & $25 \%$ & $15 \%$ & $0 \%$ \\
\hline 19 & $\begin{array}{l}\text { In the future Moodle will be a necessity for } \\
\text { teaching and learning activities. }\end{array}$ & $70 \%$ & $25 \%$ & $5 \%$ & $0 \%$ \\
\hline 20 & $\begin{array}{l}\text { The quality of teaching and learning is } \\
\text { enhanced via the use of Moodle. }\end{array}$ & $65 \%$ & $30 \%$ & $5 \%$ & $0 \%$ \\
\hline & $(13)$ & $(6)$ & $(1)$ & $(0)$ \\
\hline
\end{tabular}

Table.2 represents prominently the perspectives of the students on the implementation of a Moodle-based of SIDALACE Learning Management System (LMS) as an open-source e-learning platform for post-graduate students enrolled in the Master of English Education (MPBI) program at STKIP PGRI Sidoarjo, as depicted in the previous section. Students' attitudes toward using Moodle for learning activities were examined in three sections, each containing the following information: the benefits of using Moodle for learning activities, the actual use of Moodle for learning activities, and the students' attitudes toward using Moodle for learning activities. Thus, the Interval of response frequency showed a clear correlation between agreeing with the benefits of using Moodle and strongly agreeing with the benefits of using Moodle.

Moodle can assist students in creating learning spaces known as Courses, and it is assumed that all students agree with the first statement. It is considered to be a very good impression. As a result, the second and third statements produced identical results, indicating that they were unanimously accepted. In addition to creating a list of activities for students to complete prior to attending a lesson, Moodle has provided them with a place where they can easily create web pages with information about their course and links to word documents, PowerPoint presentations, and other resources their students will find useful. Consequently, the research question for this study arose from real professional practice contexts in authentic institutional settings, which is what this paper is about. Based 
on the literature, the current study gathered data to investigate the experience of various elearning initiatives and examined various perspectives on problems and possible solutions to the challenges of sustainability (Abdelraheem, 2012). The findings of the study were representative of those found in other studies and provide a comprehensive picture of the current challenges to e-learning sustainability across the sector.

The second section of the questionnaire consisted of five questions about how Lecturers use Moodle to facilitate their teaching activities at STKIP PGRI Sidoarjo. According to the participants, Moodle can be used for a variety of tasks including uploading video, audio, and/or links to lessons; engaging lecturers and postgraduate students in a discussion forum; facilitating real-time discussion or chat; creating, guiding, and conducting quizzes; and assigning, collecting, reviewing, and upgrading assignments. In terms of the findings, it is concluded that the implementation of e-learning was indeed efficient and beneficial, which is a very good classification for the organization. Student attitudes toward using Moodle for learning activities were found to be positive overall, according to the findings of the study. It's recommended that the system be able to meet the needs of a wide range of people, which will lead to more creative and educational projects. Collective action is needed to make this flexible method more stable and long-term than it is now (Alturki \& Aldraiweesh, 2021). This requires a lot of cross-functional collaboration to deal with different and sometimes conflicting points of view. This is just one part of the culture change that research shows are needed for e-learning to change, not just sit awkwardly next to, institutional practice (Adesope \& Ahiakwo, 2016).

The questionnaire's final section asked participants to describe their additional perceptions of Moodle's use. Contrary to expectations, the research revealed that postgraduate students at STKIP PGRI Sidoarjo saw the use of Moodle for teaching and learning activities during pandemic Covid-19 as beneficial. Moodle-based e-learning challenges numerous embedded traditions, which will require time and targeted action at various institutional levels to shift (Zwain, 2019). Willingness to work collaboratively to develop and implement strategy, as well as to develop e-learning at the practice level, is a particularly difficult target in institutions with long-standing hierarchical traditions. Indeed, a collaborative approach is insufficient to streamline institutional response times and policy development processes (Ain, Kaur, \& Waheed, 2016). This will almost certainly face the same design and implementation challenges as the e-learning initiatives for which it is intended.

\section{Conclusion}

Overall, Moodle as an open-source e-learning platform enabled educational institutions from all over the world to collaborate on projects that integrate technology meaningfully into their teaching activities, such as for post-graduate students enrolled in the Master of English Education (MPBI) program at STKIP PGRI Sidoarjo, which has implemented the platform. Moodle, while requiring significant effort on the part of lecturers, provided a means for them to engage in authentic materials in online learning during the pandemic Covid-19 era, even though it was not designed for this purpose. The findings demonstrated that using Moodle is advantageous to both lecturers and students, and that it allows them to collaborate more effectively with one another. In addition, the researchers discovered that post-graduate students had a positive attitude toward the use of Moodle for educational purposes, which was surprising to them. As a result of these findings, the study recommends that other departments at STKIP PGRI Sidoarjo prioritize course maintenance through the use of the Moodle learning management system. When 
studying general concepts of discipline courses and using them to inform specific target groups, a number of limitations should be considered, because the findings of this study may not be widely applicable. As a result, more research across a variety of disciplines is encouraged, with the goal of improving students' perceptions of their own outcomes.

The optimization of learning management system (LMS) investment in higher education as sustainability is therefore critical in order to increase participation in higher education as sustainability. Future researchers who wish to conduct similar types of research will require funding in order to publish their findings. As a result of the crisis, stakeholders should be better prepared to consider remote learning as a viable option for long-term sustainability. Despite the fact that this study demonstrates the presence of statistical evidence, it has a lot of limitations. Because the respondents for this study are all from the same university, future studies will require more respondents from a variety of majors, as well as studies of other factors such as educators' attitudes toward learning management systems (LMS) and their motivations to use them.

\section{References}

Abdelraheem, A. Y. (2012). Interaction quality in Moodle as perceived by learners and its relation with some variables. Turkish Online Journal of Distance Education, 28(3), 557-582.

Adesope, R. Y., \& Ahiakwo, R. O. (2016). Perception of Educators Towards Using Modular Object Oriented Dynamic Learning Environment (MOODLE) for Teaching. International Journal of Academic Research and Reflection, 4(3), 46-52. Retrieved from www.idpublications.org

Ain, N., Kaur, K., \& Waheed, M. (2016). The influence of learning value on Learning Management System use: An extension of UTAUT2. Inf. Dev. 32, 1306-1321.

Alameri, J., Masadeh, R. M., Hamadallah, E., \& Bani, H. (2020). Students' Perceptions of E-learning platforms (Moodle, Microsoft Teams and Zoom platforms) in The University of Jordan Education and its Relation to self-study and Academic Achievement during COVID-19 pandemic. Advanced Research and Studies Journal, 11(5), 21-33.

Alturki, U., \& Aldraiweesh, A. (2021). Application of Learning Management System (LMS) during the COVID-19 Pandemic: A Sustainable Acceptance Model of the Expansion Technology Approach. MDPI, 13(19), 1-16. doi:https://doi.org/10.3390/su131910991

Gunn, C. (2010). Sustainability factors for e-learning initiatives. ALT-J, Research in Learning Technology, 8(12), 89-103.

JO, I. H., Kim, D., \& Yoon, M. (2015). Constructing proxy variable to measure adult learners' time management strategies in LMS. Educational Technology and Society, 18(3), 214-225.

Kerres, M. (2020). Against All Odds: Education in Germany Coping with Covid-19. Postdigital Sci. Educ., 2, 690-694.

Lonn, S., Teasley, S. D., \& Krumm, A. E. (2011). Who needs to do what where?: Using Learning Management Systems on residential vs. commuter campuses. Comput. Educ. 56, 642-649.

Machado, M., \& Tao, E. (2007). BlackBoard vs. Moodle: Comparing user experience of earning management systems. 37th ASEE/IEEE Frontiers in Education Conference. Wisconsin, U.S.

Moazami, F., Bahrampour, E., Azar, M. R., Jahedi, F., \& Moattari, M. (2014). Comparing 
two methods of education (virtual versus traditional) on learning of Iranian dental students: a post-test only design study. BMC Med Educ., 14(45). doi:https://doi.org/10.1186/1472-6920-14-45

Ningrum, P. A., et al. (2020). The Potential of Poverty in the City of Palangka Raya: Study SMIs Affected Pandemic Covid 19. Budapest International Research and Critics Institute-Journal (BIRCI-Journal) Volume 3, No 3, Page: 1626-1634

Saleh, A., Mujahiddin. (2020). Challenges and Opportunities for Community Empowerment Practices in Indonesia during the Covid-19 Pandemic through Strengthening the Role of Higher Education. Budapest International Research and Critics Institute-Journal (BIRCI-Journal). Volume 3, No 2, Page: 1105-1113.

Sihombing, E. H., Nasib. (2020). The Decision of Choosing Course in the Era of Covid 19 through the Telemarketing Program, Personal Selling and College Image. Budapest International Research and Critics Institute-Journal (BIRCI-Journal) Volume 3, No. 4, Page: 2843-2850.

Widodo, J. P., \& Slamet, J. (2020). STUDENTS'PERCEPTION TOWARDS GOOGLE CLASSROOM AS E-LEARNING TOOL (A Case Study of Master of English Education of the Second Semester at STKIP PGRI Sidoarjo). Magister Scientiae,, 2(48), 99-109.

Widodo, J. P., \& Slamet, J. (2021). Lecturers' Perspectives Through E-learning by Using Moodle for Post-Graduate Students at STKIP PGRI Sidoarjo. International Seminar on Language, Education, and Culture (ISoLEC 2021) (pp. 167-171). Atlantis Press.

Zogas, S., Kolokathi, A., Birbas, K., Chondrocoukis, G., \& Mantas, J. (2016). The eLearning Effectiveness versus Traditional Learning on a Health Informatics Laboratory Course. ; 226:109-12. Stud Health Technol Inform., 109 - 112. Doi: 10.3233/978-1-61499-664-4-109

Zwain, A. A. (2019). Technological innovativeness and information quality as neoteric predictors of users' acceptance of Learning Management System: An expansion of UTAUT2. Interact. Technol. Smart Educ., 16, 239-254. 